\title{
Translators and Translation in the Early Tibetan Buddhist Renaissance
}

\author{
By \\ Matthew E. Spitzer \\ April, 2004 \\ A thesis paper Submitted in partial fulfillment of the requirements of the degree of \\ Master of Arts
}

History of Religion

Tibetan Buddhism

University of Virginia 
The rise of Tibetan Buddhism has, from one perspective, been largely a process of translation. A translation that has been both textually-based and as an act of rendering the associated cultural productions of Indian Buddhism into the new geographical and cultural medium of Tibet. This process was by necessity, not a transmission from A to B with a minimum of distortion, but a transformation by which the Tibetan version of what had been Indian Buddhism was altogether new. This paper will explicitly address the early period (950-1150 C.E.) of the translation of Buddhist materials in the so-called phyi dar, or 'Second Diffusion' of Buddhism in Tibet. Specifically this paper will look at the figure of the lo tsa ba, or 'Translator', both those of the specifically Tantric variety, such as rwa lo rdo rje grags and 'brog mi shakya ye shes, but also those that came slightly earlier and are anomalous if only because of their general disposition against being wholly categorized, such as the 'Great Translator', rin chen bzang po. These entrepreneurial religious figures drove the search for Indian Buddhist materials and the characteristics of their introduction into Tibetan understanding. Yet what we know about their directives, the specific problems they faced, and especially their motivations is extremely limited. This paper is an attempt to shed some light on these issues through not only piecing together the disjointed information we have on these individuals under this specific context, but also through looking at them in conjunction as representative of the growth of the disparate institutions whose primary directive was the importation of Indian Buddhist materials.

The figure of the lo tsa $b a$ in the beginning of the Tibetan Buddhist Renaissance (950-1250 C.E.) was one of increasing significance. If the Indian Buddhist textual and exegetical materials were rising to become the new currency of the time, these figures served as the banks that would dole out their tender in exchange for capital. The emergence of this new trade was the result of a need to reconcile the divergence in opinions regarding the materials that had been previously acquired centuries before under the royal sanctions of the central Tibetan monarchs 


\section{1}

during the snga dar, or 'Early Diffusion' of Buddhism (600-850 C.E.). These expanding perspectives flowed out of the disintegration of the Tibetan empire, generally held to be around 842 C.E. The resulting void was filled, over time, by numerous parties, including long reigning familial clans, residual aristocrats, pockets of surviving monastics from the edges of Tibet, and various other religious figures of unspecified pedigree, all of whom were beginning to make postures of religious authority in a time of renewed commercial and political stability in the mid2

tenth century. One type of figure which emerged out of the disorder of the period are the lo tsa bas, who because of their direct access to the Buddhist textual materials and Indian Buddhist themselves, became "the new lords of the Dharma" .

The memory of the prior work of acquiring Indian Buddhist materials that had been authorized by the divine royal monarchs spurred many of these groups to the rejuvenation of that earlier task. The result however, "was not an absence of information but the clamor of multiple voices. There were voices for the Vinaya, voices for the old esoteric system, and voices for philosophical discourse, all claiming that they should be given pride of place in the coalescence 4

of the culture." At the onset many began to seek out Indian teachers to both verify what had been acquired previously and to take the knowledge of Buddhism in Tibet even further. The task was one primarily of textual translation and re-translation, both of the primary texts of Indian Buddhism and any new material produced in India during the intervening years. rin chen bzang po is a primary example of the early lo tsa bas who, possibly without significant patronage,

Davidson, Ronald. Tibetan Renaissance: Tantric Buddhism in the Rebirth of Tibetan Culture and the Rise of the Sakya, Unpublished Manuscript, 2004, pg. 150.

ibid, see chapters $2 \& 3$.

ibid, pg. 149.

ibid, pg. 150. 
journeyed over the Himalayas to Kashmir, Nepal, and India proper to seek out learned Buddhists who could assist in making sense of the texts extant in Tibet and in bringing back Buddhist materials to further the task previously uncompleted. The assistance they would receive however was not always one of clarification.

The organization of these missions for young Tibetans to learn, acquire and return with Buddhist knowledge and texts continued to increase up until India was no longer the compelling seat of all Buddhist knowledge, as most of the loci of Buddhist learning were disappearing from India at the hand of Turkic invaders starting in the $13^{\text {th }}$ century. Increased patronage and direction did not however solve many of the problems that these fact-finding missions were meant to alleviate, issues that primarily revolved around the antinomian behaviors associated with many of the previously translated Tantras. As will be seen, while there was indeed a clamor of voices within Tibet, there was an equal, if not greater number of voices coming up from India, some created on the spot, out of which the translators were left to make some semblance of order. Many, like rwa lo rdo rje grags and 'brog mi sakya ye shes made significant interpretive moves in this regard that would profoundly affect not only their own lives and those around them, but also the institutions that would stem from their teachings upon returning to Tibet. The reality of these bi-directional voices can be seen in a number of ways through both the concerns of the Tibetan patrons of the lo tsa bas and those of the Buddhist masters that they worked with.

The mark of the beginning of the phyi dar is considered by many historians to have been 5 initiated by the work of rin chen bzang po who was born in 958 C.E. and returned from his first

Roerich, George, trans. The Blue Annals. Delhi: Motilal Banarsidass, 1976, pg. 68. 
6

trip to Kashmir in 987 C.E.. The majority of his life was spent in the kingdoms of gu ge and pu

hrang of the western region of mnga' ris, and his association with the ruler-turned-monastic lha la 7

ma ye shes 'od is clearly made in both the Blue Annals and his primary rnam thar. While there

had been small pockets of monastics preserved here just as there had been in Eastern areas like 9

Tsongkha , most chos 'byung (religious histories) speak of the years prior to the phyi dar as

rampant with all manner of tantric practices, many of which were considered to be wrong in their

10

literal interpretations of activities depicted in the tantras themselves. In the chos 'byung of bu

ston, written in the $14^{\text {th }}$ century, the author mentions rin chen bzang po and lha la ma ye shes 'od specifically as the primary proponents of the view that the prevailing interpretations of the early 11

rnying ma tantras, especially the yoga tantras, were not the "true teaching". One then assumes

that it was the desire to rectify these trends, or at the very least to revisit the translations that spawned them, that served as the impetuous for ye shes 'od to send 21 youths to Kashmir to study Buddhism, rin chen bzang po among them.

Vitali, Roberto. The Kingdoms of Gu.ge Pu.hrang: According to mNga'ris rgyal.rabs by Gu.ge mkhan.chen Ngag.dbang grags.pa. Tho.ling gtsug.lag.khang lo.gcig.stong 'khor.ba'i rjes.dran.mdzad sgo'i go.sgrig tshog.chung; Dharmsala: India, 1996, pg. 186. Note that Tucci in his treatment of rin chen bzang po shortens the first trip to Kashmir by 2 or 3 years bringing him back to Western Tibet around 985 C.E. See Tucci, Giuseppe, and Chandra Lokesh. Rin-Chen-Bzang-Po and the Renaissance of Buddhism in Tibet around the Millennium (Indo-Tibetica II). New Delhi: Aditya Prakashan, 1988, pg. 61.

Roerich 1976, pp. 68-69.

The rin chen bzang po'i rnam thar, [TBRC\# W18638], see Tucci, 1988, pg. $53 \mathrm{ff}$.

Davidson, 2004,pg. 13.

Karmay, Samten. "The Ordinance of Lha bLa-ma Ye-shes-"od". In Tibetan Studies in honor of Hugh Richardson. Eds. Aris, Michael Aung San Suu Kyi, Proceedings of the International Seminar on Tibetan Studies Oxford 1979; Warminster, England: Aris \& Phillips, 1970, pg 152.

Obermiller, E. The History of Buddhism in India and Tibet by Bu-ston. Sri Satguru Publications, Delhi, India, 1986, pg. 212. 
The missions that could potentially clarify the tantric practices, in as far as they may have been exhibited in the western kingdoms at this time, undoubtedly contributed to the continual patronage received from these kings, extending for many generations past ye shes 'od as we will see in the case of rwa lo rdo rje grags. Yet as to whether this is the same directive that sent rin chen bzang po on such a dangerous trip over the Himalayas to climates drastically different from his own home is not as certain. The mention of early patronage by the kings of mnga' ris is

largely absent from the information contained in the various rnam thar of rin chen bzang po.

Nor do the primary historical accounts of the period, written in the $14^{\text {th }}$ and $15^{\text {th }}$ centuries, mention specific directives at this early stage in the rejuvenation of Buddhism. What is clear is that around the very same time of rin chen bzang po's return from Kashmir, lha la ma ye shes 'od issued a bka' shog, or ordinance, offering a criticism and warning for "Tantrists" engaged in 14

questionable practices. Ye shes 'od warns specifically against the practices of sbyor and sgrol, or sexual practices and liberation by killing. He says,

As 'sexual rite' has become popular the different classes of people are mixed ... As the ritual of sacrifice has become popular it happens that people get delivered alive. . .

Is this the practice of the Mahayana? ...

Ignorant about the signification of 'implicit' 15 nd therefore practicing it literally,

You, Mahayanist, may be born as a demon.

Vitali, 1996, pg. 187 and Tucci, 1988, pp. 58-59.

The exception to this is Tucci's apparent use of the chos 'byung btsan pa'i padma rgyas pa'i nyin byed of pad ma dkar po which give some details of invitations to Indian masters and specific texts that were supposed to be learned by rin chen and his contemporaries. I was however unable to look at this source to see exactly what is detailed and Tucci is unclear about he specifically takes from this source.

Karmay, 1970, pg. 152, but Vitali calls to question the precision of Karmay's dating, placing the date for ye shes 'od's bka' shog after the initial return of rin chen bzang po instead of just prior to it- see Vitali, 1996, pg. 239.

From Karmay's translation, pg. 154. 
From this it may be more accurate to conclude that the rise of patronage to investigate these tantric practices resulted not in the directive for rin chen to travel to Kashmir and clarify the sources with Indian masters, but instead was the result of his travels there and the understanding he acquired. Following his initial period of study, rin chen was all the better informed to influence such a statement, issued so definitively by ye shes 'od, who seems to have still been 16 serving in an official capacity. In addition, the issuance of this statement comes more than a decade after rin chen's initial departure and offers no evidence to suggest that a similarly specific directive informed his own trip. Vitali concludes even more definitively that rin chen bzang po made his first trip to Kashmir largely of his own accord, before lha la ma ye shes 'od had the 17

means or popular backing to support such a trip. While there does not seem to be any accounts detailing significant coordination in this regard, Vitali's own translation of the mnga' ris rgyal $r a b$, includes details of the compensation of the parents of rin chen and the other 20 young men sent at this time, 19 of which would die in the process.

Who rin chen bzang po studied with on this first trip and which of his many translations may have been done at this time is also left out of the biographical sources. This information could potentially provide additional clues about the goals and objectives rin chen may have had during his first trip, how he attempted to complete those goals, and how these changed over time. Further, additional chronologies in this regard could speak to the influences on this early translator and the interpretation he would give to the materials acquired in Kashmir and elsewhere. Upon his return, there is no doubt that his newly acquired recognition, and therefore wealth, went a long way in establishing his position as a figure of great knowledge and ability,

Vitali, 1996, pg. 239.

ibid, pp. 187-8.

Ibid, pg. 109. 
and possibly even influencing ye shes 'od to warn against other who may now be said to be practicing incorrectly.

Based both on the colophons of extant materials attributed to rin chen as well as the textual material associated with him in various historical sources, it is clear that he dealt significantly with both the Prajñaparamita literature and the Tantras and their commentaries.

rin chen is said to have been prolific in both regards: "Others could not compete with him in his daily work, such as the erection of images and translation of (sacred texts), etc" ${ }^{20}$ and he "mastered and expounded all the basic texts of the Pajñāparamita and Tantra classes, [and] has especially expounded the Yoga-Tantras." 21 Indeed, one of the accolades bestowed on rin chen by

a later king of gu ge was rdo rje slob dpon, or vajra master, attested in multiple sources. The Guhyasamaja Tantra in particular received much attention from rin chen, having been one the first to revisit this text in the phyi dar and to translate its primary commentaries, such as the 23

Pradīpodyotana. It is his activity as 'translator' that typifies what we know about this early figure, and barring his dates, travel to Kashmir, and meeting with Atiśa addressed below, every reference to him in the Blue Annals is restricted to his foundational translation work.

The subsequent trips taken by rin chen to Kashmir and perhaps India as well, establish that he was the recipient of increasing patronage and specific directives at the behest of the kings of gu ge and pu hrang. After his first round of travels, rin chen had achieved the status a learned

See Tucci, 1989, pp. 40-9 for a list of colophons mentioning rin chen bzang po, and Roerich, 1976, pp, 209, and 351-2 for commentary regarding the texts commonly associated with him.

Roerich, 1976,pg. 69.

ibid, pp. 351-2.

Roerich, 1976, pg. 68, Tucci, 1988, pg. 63, and Vitali, 1996, pg. 187.

Roerich, 1976, pg. 359. 
Buddhist scholar at a time when few could claim a similar educational level or source. On these subsequent trips, rin chen was charged to return with not only additional textual materials, but also artisans and artwork, with which the infrastructure of Tibetan Buddhism could continue to be 24

built. Significant numbers of temples and monasteries in western Tibet are traced back to the work of rin chen and those he brought back with him, and "the living tradition . . . continues to see him as primarily responsible for all the impressive Buddhist works in western Tibet during the 25

$10^{\text {th }}$ and $11^{\text {th }}$ centuries" . This non-textual element of rin chen's role as translator may just be his most visible and long lasting one.

That rin chen taught throughout his life and gained numerous disciples of various interests attests to his wide acceptance as a teacher of both tantric and non-tantric materials. Yet the doubts concerning the general direction and flavor of the new Buddhism must have persisted irrespective of rin chen bzang po's ability to translate and instruct on these matters. The invitation to invite the Indian master Atiśa seems to have been a goal of king ye shes 'od and his nephew and successor, byang chub 'od, for some time, both repeatedly sending emissaries on 26

their behalf to invite the Bengali to Tibet. Finally rngog lo tsa ba was successful in 1040-1 C.E., having departed some three years earlier, and then began the journey with Atiśa back to 27

mnga' ris. While the arrival of Atiśa is depicted as a seminal moment in the Buddhist history of Tibet, his arrival does not seem to have been the panacea as it is sometimes represented.

Tucci, 1988,pg. 66.

Snellgrove, David L. and Skorupski, Tadeusz, The Cultural Heritage of Ladakh. Boulder: Prajña Press, 1977, vol. 1, pg. 19.

Decleer, Hubert. "Atiśa's Journey to Tibet." Religions of Tibet in Practice. Ed. Donald S. Lopez. Princeton, NJ: Princeton University Press, 1997, pg. 158

ibid, pg. 159. 
When rin chen and Atiśa meet upon the latter's arrival in western Tibet via a long stay in Nepal, the need for his journey is justified given the unsatisfactory condition of the lo tsa ba's understanding of tantric practices. Their interaction, recorded in slightly varying editions, shows that Atiśa is impressed with the number of texts known by rin chen, but how he understands them as a whole causes a strong reaction from the visiting scholar:

The lo tsa ba replied: "Indeed, one should practice according to each (Tantra) separately."

The Master exclaimed: "Rotten is the lo tsa ba! Indeed there was need of my coming to Tibet! All these Tantras should be practiced together".

As Snellgrove rightly comments on this episode, this is a curious exchange. Given the familiarity of both men with a wide range of tantric systems, a common dialogue about these systems and 29 their organization for a single practitioner should not have varied so widely.

However, this is exactly the kind of exchange, no doubt occurring in a myriad of ways between Indians, Kasmiris, or Nepalis and the Tibetans who have sought them out, asking for clarification of material where multiple positions are easily found. Whether the issue is sbyor or sgrol practices, or the opinions concerning guhyābhișeka or Prajñäbhișeka, it all depends on whom you ask. These issued presented "serious problems in the domains of both interpretation 30 and practice" in Western Tibet in the $11^{\text {th }}$ century. These problems were not lost on the kings and masters of Western Tibet, and here they may well have been more acute than elsewhere in Tibet. These matters are also not restricted to esoteric material. Lang has pointed out a similar issue in the conceptualization of Madhyamaka material, where some confusion persisted well into

Roerich, 1976, pg. 249. For an alternation rendition see Snellgrove \& Skorupski, 1977, vol. 2, pg. 96.

Snellgrove, David L., Indo-Tibetan Buddhism: Indian Buddhists and their Tibetan successors. Boston: Shambhala; 1987, pg. 202.

Ruegg, D. Seyfort. "Problems in the Transmission of Vajrayana Buddhism in the Western Himalaya About the Year 1000". In Acta Indologica 6, 1984, 369-381. 
31

the $11^{\text {th }}$ century until the work of spa tshab nyi ma grags (b. 1055 C.E. ) sufficiently 32 differentiated between Candrakīrti and Bhāvaviveka's work. Until that time, a distinction between the two was unclear to Tibetans studying this philosophical material in the phyi dar. Even the master Atiśa seems to have been unclear about his presentation of the Madhyamaka in his Bodhimārgadīpapā̃njikā, the commentary to the Bodhipathpradīpa, the text he composed at the request of the king of gu ge in order to help clarify the Mahayana path and the role of tantric 33

practices. Given that the Madhyamaka treatises generally offer significantly fewer barriers to interpretation, a confusion of similar magnitude concerning esoteric materials seems unsurprising.

The life of rin chen bzang po typifies what must have been an expanding field of young men looking to make their livelihood trading in the new commodity of the period. As we turn to consider two figures from the subsequent generations of lo tsa $b a$, rin chen bzang po stands out if only because of the types of practices that are not associated with him. Perhaps because of the kind of entrepreneur that began to populate the ranks of lo tsa bas, or because the hermeneutical issues highlighted in Atiśa's treatment of rin chen, these figures are increasingly associated with practices that many in positions of power and emerging Buddhist groups were hoping to sort out, namely sbyor and sgrol practices. These activities, claimed to arise directly from the study of tantric material, as well as the accumulation personal wealth, became increasingly paradigmatic.

Although 'brog mi sakya ye shes (990?-1043? C.E.) started his career near lha rtse in eastern Tibet, and with significant differences from the political and religious environment western Tibet, the information we have about his travels and subsequent career illuminate many

TBRC\# P5651.

Lang, Karen. "Spa-Tshab Nyi-ma-gragss and the Introduction of Prasangika Madhyamaka into Tibet." In Reflections on Tibetan Culture: Essays in Memory if Turrell V. Wylie, eds. Epstein, Lawrence and Sherburne, Richard F.. Lewiston, NY: E. Mellon Press, 1990, pgs. 127-141.

Lang, 1990, pp. 131-2 and Ruegg, 1984,pg. 372. 
of the trends we have seen thus far for lo tsa bas of the early phyi dar. Very little is known about 'brog mi prior to his travels to Nepal and India beyond the various biographical and historical sources which maintain that his ordination at grom pa rgyang was facilitated by several teachers 34

from central Tibet around 1008. Most significantly, these same sources give an ostensible account of 'brog mi and his contemporaries' appointed task as they were sent off to Nepal and India not long after his ordination. Go lo tsa ba gzhon nu dpal quotes his source directly in the Blue Annals, giving the instructions fro 'brog mi and his companions delivered by sakya gzhon nu and se ye shes brtson 'grus:

"Listen to the (exposition) of the Vinaya for it is the Basis of the Doctrine. Listen to the Prajñāpāramitā, for it is the Essence of the Doctrine. Listen to Vajrayāna, for it is the Spirit of the Doctrine."

While this three-fold division may be vague, it shows that the institutions behind some of these expeditions to facilitate Buddhist learning were making at least a gesture of being interested in all aspects of the Dharma, and not just the esoteric rituals and the worldly benefits gained from them. It seems that while the same sources mention 'brog mi's study of the first two parts of the Doctrine, most if not all of his translations concern esoteric material, primarily the yoginī 36 tantras.

His first stop on the way to learn these materials was Nepal, a common acclimatization area for Tibetans descending from the high plateau. A stop at the centers of Buddhist learning, primarily in the city of Patan, or Lalitpur, became paradigmatic for Buddhist travelers, both coming and going. Even Atiśa would stay there on his trip to mnga' ris with ngog, an interesting

Roerich, 1976, pg. 205. This date is based on the association of 'brog mi's activities with the time when rin chen bzang po was in his fiftieth year.

ibid, pg. 206.

ibid, pp. 205-6. 
stop over since such extended reverse acclimatization is unnecessary. 'brog mi stayed there for a year, and his first subject of instruction there was "secret mantra." 37 In fact the majority of Tibetans stopping over in the Kathmandu Valley who would do any significant study during their time there were mainly educated in tantric ritual systems, and rwa lo rdo rje grags who we will discuss shortly is no exception. Little work has been done to independently address the nature of the Buddhist institutions of learning in Nepal in the centuries when Tibetan pilgrims seem to have been a regular fixture there, but their affect on those travelers is unmistakable. 'brog mi's first experience with long-term textual instruction was under the tutelage of an individual with the title 38

of bharo, or Bha ro Ham thung. The titles and identities of many teachers in Patan are less than clear, and confusion abounds concerning the use of Sanskrit, Newari, or Tibetan names of these individuals. While only a short period of 'brog mi's decade long trip was spent in Nepal, Stearns mentions at least one source that maintains 'brog mi did not wish to move on to further study in India so quickly, but agreed to go in order to not separate from his original 39

companions. His Newar instructor gave them perhaps obvious advice on where to go, and so 'brog mi set out for Vikramaśila in India proper.

There 'brog mi is said to have studied with all of the great masters of Vikramaśila at that time, studying with each gatekeeper their specialty. After completion of the course of study there 'brog mi traveled to southern Bengal to visit Khasarpana. On his way there he would encounter a monk who would initiate 'brog mi into various esoteric systems, including those of

Stearns, Cyrus. Luminous Lives: The Story of the Early Masters of the Lam 'bras Tradition in Tibet. Boston: Wisdom Publications, 2001,pg. 85.

ibid, pg. 85 .

ibid, pg. 207, n.16.

Roerich, 1976, pp. 205-6. 
Virupa, who is associated with the origins of the lam 'bras teachings. After some additional years spent studying with this monk variously identified as Prajñendraruci or Vīravajra and these further tantric systems, 'brog mi eventually returned to Tibet after a decade or more, and is reported to have made his earlier teachers quite pleased with his accumulation of knowledge 42

abroad.

In the short example we have from this one lo tsa ba's travels, we can see that his training was anything but uniform, and in fact, probably had more variation than most. Starting with esoteric teachers of largely unknown lineage, completing a standardized education at a highly institutionalized monastic seat of Indian Buddhism, and then engaging in impromptu instruction from siddha figures of the lineage of Virupa, 'brog mi returned to Tibet to teach these traditions and repay the investment made in him a dozen years earlier. But the disparate influences Indian Buddhism would make on 'brog mi would not end once he re-crossed the Himalayas and established himself as a learned scholar of Buddhism. Indeed his most influential engagement would occur when the Indian paṇita Gayadhara arrives and offers further opportunity for instruction.

'brog mi's entrepreneurial spirit is perhaps unsurpassed in the early phyi dar. Similarly to rin chen bzang po, 'brog mi became established as significant figure who would attract a large number of students. How the historical sources differ with 'brog mi in this regard are the high

prices that he would then charge for access to the knowledge he had labored to acquire. This, along with his negotiated terms for the instruction he would receive from Gayadhara, have

Stearns, 2001, pp. 87-89. Also Roerich, 1976, pg. 206.

Roerich, 1976, pp. 206-7.

Roerich, 1976, pp. 208, 399. And in particular mar pa was inspired to go to India himself because of the inaccessibility of the teachings a result of 'brog mi's exorbitant fees. 
contributed to "brog mi's depiction as the "quintessential greedy lama" . While there are other instances of Indian scholars coming to Tibet prior to this time, even some returning with rin chen to mnga' ris, 'brog mi's exclusive relationship with Gayadhara appears unique. 'brog mi realized that Gayadhara was a holder of the lineage of Virupa, whose system he had started learning just prior to his return to Tibet. More importantly, 'brog mi moved to capitalize on this connection and requested that Gayadhara instruct 'brog mi exclusively, for which he would be well 45 compensated.

The career path that 'brog mi and others were beginning to carve out for themselves was surely becoming a highly competitive one. This move by 'brog mi would ensure his own position as the broker for the knowledge and instruction he had originally gained abroad and now additionally all of the instruction he would garner from an Indian directly in their midst. Davidson's treatment of 'brog mi and Gayadhara is extensive and does not need to be reproduced 46

here. The most significant product of their relationship is the translation of the lam 'bras rtsa ba, or the Root text of the Fruit \& Path, the text for which 'brog mi would become the most famous. Davidson concludes that this text is a prime example of the numerous 'gray texts' being produced at this time as a result of collaboration between Tibetans and Indian Buddhists. $\quad{ }^{47}$ Texts such as this and perhaps many others, never existed in India, but were instead composed in Tibet, thru collaboration. The composition as such served the needs of both participants - to be compensated for the desired instruction on the part of the Indian, and to be associated with what

Davidson, 2004,pg. 206.

Roerich, 1976, pg. 207.

Davidson, 2004, pp. 223-253.

ibid, pg. 233. 
one would hope would become a preeminent teaching of the day. In the case of the lam 'bras rtsa $b a$, Davidson also concludes that its highly peculiar nature and impenetrable style are all the more likely a part of 'brog mi's plan to limit its exposition to himself alone.

The life and work of 'brog mi sakya ye shes clearly shows that even with the intentions of making sense of the many voices coming from within Tibet, one can meet with an equal number of voices in the Buddhist world of the sub-continent. The means by which one would then attempt to present a cohesive picture of these various voices can take on variety of formats. In 'brog mi's case, the text he translated with the help of his Indian pandita, was such that 'brog mi was in significant control of who else would be positioned to teach its parts, so that no one individual could rival his own comprehensive grasp of the material. The result is an interpretive bottleneck in the transformation of Indian materials into the Tibetan landscape. 'brog mi's lineage of lam 'bras material would develop into a major part of what would become the sakya pa sect of Tibetan Buddhism - a clear indication that engaging in clarification and making sense of these traditions does not always translate into good business sense for a career lo tsa ba.

The last lo tsa $b a$ we will look at, rwa lo tsa ba rdo rje grags, rounds out this eclectic group. His inclusion in this analysis is precarious if only because of the amount of conflicting information we have on this figure. On the one hand we have an image of an individual who establishes himself through the excellence of his translations and spends a significant portion of

his income renovating and making offerings to monastic establishments. On the other, we have an individual known for his study of tantric magic in Nepal, which he then most notoriously used in battles of pride and for the 'ritual killing' of numerous individuals including mar pa's son, dar

Ibid, pp. 182-4.

Roerich, 1976, pp. 376-7. 
ma mdo sde. Part of the conflict may well in fact be that the dates for his life are far from

conclusive. The general and often quoted date given for his birth is 1016 C.E. , although this is

not stated as such in either the Blue Annals, in which rwa lo is mentioned more than a dozen times, or in his primary rnam thar. Decleer concludes that this date of birth for rwa lo is derived circuitously; that the year is established by subtracting his age at death from the date he passed 52

away. The problem with this calculation is that his rnam thar states that he lived to be 180

years old, and that his death is known to be exactly at "sunrise of the $10^{\text {th }}$ of the IVth month of the 53

Horse Year", this being 1198 C.E. Yet even here, the calculation does not hold up, being off by two years.

The problem this presents us with is in figuring out exactly how rwa lo got his start as a 54

lo tsa $b a$ and whether he was contemporaneous with 'drog mi and mar pa (b. 1012 C.E. ) or 55

with rngog lo tsa ba (b. 1059 C.E. ). In the Blue Annals there are no less than three references to rwa lo being in attendance at the chos 'khor (religious council) of 1076 C.E. held by king rtse 56 lde, a king of mnga 'ris in the same line as lha la ma ye shes 'od. The mnga' ris rgyal rab

Decleer, Hubert. "The Melodious Drumsound All-Pervading: Sacred Biography of Rwa Lotsāwa: about early Lo tsa wa rNam thar and Chos 'Byung". In Tibetan Studies: Proceedings of the 5th Seminar of the International Associaton for Tibetan Studies, 1992, pp. 13-28.

pod rgya tshig mdzod chen mo, 1998, pg. 3214.

Decleer 1992, pg. 20, n. 8.

ibid, pg. 20, n. 8 .

Trungpa, Chögyam. The Life of Marpa the Translator by Tsang Nyön Heruka. Translated from the Tibetan by the Nalanda Translation Committee under the direction of Chögyam Trungpa. New Delhi: Shambala, 1999, pg. xxvi.

Roerich, 1976, pg. 328.

ibid, pp. 71,325 , and 328 . 
attests that 121 masters and disciples from outside mnga' ris were invited, and many more local masters attended. rwa lo may simply have been in attendance at this gathering, or may even have 57

been a name added to the list to embellish the event in the royal chronicle. However, the Blue Annals further adds that rwa lo was sent from this council to India and Nepal with gnyan lo tsa 58

ba, giving the impression that he was one of many youths organized under this council to further seek out instruction at Buddhist institutions in India. His attendance at this council and subsequent journey to Nepal for a stay of 15 years is also attested in the gshing rje gshed chos 59

'byung of Taranatha. The same source relates that at some point in his stay there, rwa lo sent an emissary back to mnga' ris to ask for further financial assistance - to which his request was 60

granted. Following his long period of study abroad, rwa then apparently follows the same pattern that we have seen before, returning home and establishing himself based on the extent of his knowledge and the attraction of students.

The alternate beginning for rwa lo is depicted in the kun khyab snyan pa'i rnga sgra, The Melodies Drumsound All-Pervading composed by rwa ye she seng ge. Here the beginning of rwa lo's studies comes after a reluctant marriage at eleven years old, and a growing desire to travel to 61 Nepal. rwa lo studies diligently in the ngag pa tradition of his father, spending some of his adolescence in retreat. After repeated visions of Heruka, he knows his real lama will be found in Nepal. Following the kidnapping of his bride by a rival, he departs to Nepal in order to begin his

Vitali, 1996, pg. 319.

See Roerich, 1976, pg. 71.

Vitali, 1996, pg. 338.

ibid, pg. 338.

Decleer, 1992, pg. 15. 
studies. This alternate biographical detail, seemingly in direct conflict with his association with the chos 'khor in mnga' ris in 1076 C.E., would be less difficult to deal with if it was the only source for such events. However, Taranatha's gshing rje gshed chos 'byung details a very similar event in addition to including the later details of his travel to Nepal under the patronage of the kings of mnga' ris. The important difference lies in that Taranatha's account relates a reluctant engagement gone sour (on her behalf) when rwa lo is a teenager, but not quite as young as the other account. In addition, Taranatha's account has rwa lo journeying to Nepal as a monk's 62

servant for a distant relative. From this we may tentatively conclude that rwa lo may in fact have been engaged or married, but then decided to pursue his studies in Nepal. In what capacity he made the trip, it is difficult to be sure. His association with the chos 'khor of 1076 C.E. is at least possible given his dates, however flawed they may be. For an intelligent young man willing to leave home and make the journey, the opportunity may have come from a religious council looking to hire many young men for such a trip.

While the dates, exact associations and motives for his trip are by no means definitive, much of the rest of his life is less contradictory. Rwa lo studies in Nepal for many years, focusing 63

primarily on the Vajrabhairava, Vajravārahī and Yamāntaka cycles of teachings. His teacher is identified simply by the title 'Bharo', the same as 'brog mi's teacher. Our first taste of rwa lo's disposition toward ritual magic comes in his battle with a local Śaivite magician named 64

Pūṛnakāla. $\quad$ rwa lo invokes rites learned from his master and so thoroughly avoids Pūṛnakāla's attempts on his life, his enemy commits suicide. After completing his first round of studies, rwa lo returns to his home and uses these same abilities to take care of the previous issue of his

ibid, pg. 16.

Roerich, 1976, pp. 374 and 396.

See Davidson's summary of these events, 2004, pp. 167-175. 
kidnapped bride. rwa lo's fame and wealth begin to grow as he attracts disciples and warns off competitors with his displays of tantric abilities. These same powers may have also attracted individuals hoping to successfully compete with rwa lo and therefore steal his growing prestige. One such occurrence is supposedly the reason behind rwa lo's implication with the death of dar ma mdo sde, mar pa's son. Davidson also recounts several other instances of rwa lo's questionable behavior, no the least of which included the taking of multiple consorts, one being just eleven years old (a familiar age for rwa lo) and killing as many as thirteen tantric masters in 65 battle.

While rwa lo would become infamous for these public displays of powers, they are curiously absent from histories like the Blue Annals. Instead, this History recounts the extreme 66 wealth rwa lo accumulated through the fees he charged for instruction. His infamy seems to have been almost rivaled by his generous allotments of funds for restorations, copies of scriptures, and recitations to be made all over Tibet and at significant Buddhist locations in India. The most famous of which is the large sum he spent to fix some fire damage and restore a 67 courtyard at bsam yas gom pa.

Rwa lo represents a significant phase in the rise of the lo tsa $b a$ in Tibetan Buddhist History. No longer was the task one of clarification or doctrinal development as we saw with rin chen bzang po, nor was it one of personal embellishment by means of textual expansion and aggrandizement like 'brog mi. With rwa lo, the task has become the establishment of personal charisma through associations with magical abilities gained through a tantric education and philanthropic donation in support of the infrastructure of Buddhism in Tibet and India.

Davidson, 2004, pg. 171

Roerich, 1976, pg. 377.

ibid, pp. 377-379. 
Throughout the chronicles of Tibetan history, the $11^{\text {th }}$ century is increasingly populated with figures making a name for themselves. mar pa, mi la re pa, gam po pa, and many others begin to appear as figures around which others can rally and even more can claim affiliations. The more renowned figures, and perhaps the minority, are those that attracted attention for their displays of magic and actions in conflict with a variety of groups. These latter-type figures serve as lightning rods for later sectarian formations precisely because they are famous, regardless of what they are famous for. A famous name for endorsement carries a significant weight, no matter what you are selling. rwa lo's defense of his actions are purely utilitarian, "I killed many men and horses. Because it is the means required to take the office of local lord ..."

In these three figures, although they are not a single cohesive group as others may be, nonetheless show a distinct evolution in the organization and patronage directed at the figure of the lo tsa ba in the early phyi dar period. rin chen may have ventured largely on his own, but his success spurred further investment by the kings of gu ge and pu hrang of missions to India and Kashmir. 'brog mi and his group are given instructions on what to accomplish during their trip, and it seems they are for the most part successful, having been educated in part as the prestigious institution of Vikramaśila. If rwa lo was associated with the chos 'khor of 1076, of which ngog lo tsa ba was also a part, this just may have been one of the most highly organized and successful of translation efforts in the early phyi dar. At the same time, the increased systematization did not always correlate into increased levels of clarification. What the patrons of western and central Tibet could not control was with whom these young men would first sit at the feet of, hanging off their every word. Nor was there any guarantee that they would then return with the Rosetta stone, putting all previous misconceptions aside.

From the rwa lo tsa ba'i rnam thar, quoted in Davidson, 2004, pg. 175. 
Much of what these young men were charged with accomplishing was impossible. They were sent to Indian in order to make sense of a body of teachings that any individual Indian master would be hard pressed to provide. That these early translators acquired their training from a variety of sources, brought these back to Tibet and used them in a dialogue of an already highly fragmented nature did almost the opposite of what many had hoped they would do - provide order. Both within these particular individuals and in the fledgling associations of Buddhist learning, these dialogues of chos would undoubtedly remain contentious. Eventually all manner of teachers could claim "Indian" sources for their practices, and most did, regardless of the reality of the situation. The determining factors of which traditions succeeded and which faded over time seems to be more closely tied, not with the evidence of purity of Indian pedigree for this could be created when needed, but with the charisma of those that made this new commodity their livelihood.

The classification of the tantras in the $10^{\text {th }}$ and $11^{\text {th }}$ centuries was still largely in a fluid state. rin chen primarily directed his attention to yoga tantras, 'brog mi to yoginī tantras, and rwa lo to mahayoga tantras, but these are all later typologies. The esoteric systems of the period propelled many careers, and in the process of sorting them out, Tibetan Buddhism emerges. Those who could not compete faded to history, and those that left their mark are upheld as the inspiration of sectarian formulations.

In all of thee cases, the geographical disparities of Buddhist systems brought together at specific times and places seems to be a significant factor. If the kings of gu ge had not sought out the Bengali master Atiśa, the differences between him and rin chen, who had studied in Kashmir, would not have been known. If 'brog mi had proceeded directly to Vikramaśila his career may very well have been significantly different than it was. These issues and others make the need for further localization in our understanding of these esoteric systems all the more important. What was being taught in Nepal is largely unknown, but its impact on the development of esoteric 
elements of Tibetan Buddhism was not insignificant. The same can be said for each locality that had direct interaction with Tibetan lo tsa bas during this period. Is there a correlation of types of esoteric systems and where the translators traveled and received their teachings?

The available historical and bibliographic sources allow only a cursory organization of the trends and influences on this extraordinary group who would have such profound affects on the nature of Tibetan Buddhism and its institutions. The issues of interpretation seen in these and other examples from the lives of the lo tsa bas highlight the degree to which the task of translation is one profoundly affected by the variables of time and place. The problems of praxis and exegesis, especially for esoteric materials, are not always immobilizing dilemmas. In the case of the translators of the Early Tibetan Buddhist Renaissance, these same problems created room for innovation and creativity that would overwhelmingly shape the tradition's formation and outcome. 


\section{Works Cited}

Davidson, Ronald. Tibetan Renaissance: Tantric Buddhism in the Rebirth of Tibetan Culture and the Rise of the Sakya, Unpublished Manuscript, 2004.

Decleer, Hubert. "Atiśa's Journey to Tibet." Religions of Tibet in Practice. Ed. Donald S. Lopez. Princeton, NJ: Princeton University Press, 1997, pp. 156-177.

Decleer, Hubert. "The Melodious Drumsound All-Pervading: Sacred Biography of Rwa Lotsāwa: about early Lo tsa wa rNam thar and Chos 'Byung". In Tibetan Studies: Proceedings of the 5th Seminar of the International Association for Tibetan Studies, 1992, pp. 13-28.

Karmay, Samten. "The Ordinance of Lha bLa-ma Ye-shes-'od". In Tibetan Studies in honor of Hugh Richardson. Eds. Aris, Michael Aung San Suu Kyi, Proceedings of the International Seminar on Tibetan Studies Oxford 1979; Warminster, England: Aris \& Phillips, 1970.

Lang, Karen. "Spa-Tshab Nyi-ma-grags and the Introduction of Prasangika Madhyamaka into Tibet." In Reflections on Tibetan Culture: Essays in Memory if Turrell V. Wylie, eds. Epstein, Lawrence and Sherburne, Richard F.. Lewiston, NY: E. Mellon Press, 1990, pp. 127-141.

Obermiller, E. The History of Buddhism in India and Tibet by Bu-ston. Sri Satguru Publications, Delhi, India, 1986.

Roerich, George, trans. The Blue Annals. Delhi: Motilal Banarsidass, 1976.

Ruegg, D. Seyfort. "Problems in the Transmission of Vajrayana Buddhism in the Western Himalaya About the Year 1000". In Acta Indologica 6, 1984, pp. 369-381.

Snellgrove, David L., Indo-Tibetan Buddhism: Indian Buddhists and their Tibetan successors. Boston: Shambhala; 2002.

Snellgrove, David L. and Skorupski, Tadeusz, The Cultural Heritage of Ladakh. Boulder: Prajña Press, vol. $1,1977$.

Stearns, Cyrus. Luminous Lives: The Story of the Early Masters of the Lam 'bras Tradition in Tibet. Boston: Wisdom Publications, 2001.

Trungpa, Chögyam. The Life of Marpa the Translator by Tsang Nyön Heruka. Translated from the Tibetan by the Nalanda Translation Committee under the direction of Chögyam Trungpa. New Delhi: Shambala, 1999.

Tucci, Giuseppe, and Chandra Lokesh. Rin-Chen-Bzang-Po and the Renaissance of Buddhism in Tibet around the Millennium (Indo-Tibetica II). New Delhi: Aditya Prakashan, 1988.

Vitali, Roberto. The Kingdoms of Gu.ge Pu.hrang: According to mNga'ris rgyal.rabs by Gu.ge mkhan.chen Ngag.dbang grags.pa. Tho.ling gtsug.lag.khang lo.gcig.stong 'khor.ba'i rjes.dran.mdzad sgo'i go.sgrig tshog.chung; Dharmsala: India, 1996. 